\title{
Microbiological contamination of toothbrushes and identification of a decontamination protocol using chlorhexidine spray
}

\author{
Contaminação microbiológica e determinação de um protocolo \\ com clorexidina spray como descontaminante de escovas dentais
}

\begin{abstract}
Purpose: This study evaluated the rate of microbial contamination of toothbrushes used by students and established a protocol for the spraying of $0.12 \%$ chlorhexidine to decrease the bacterial presence on the bristles of the brushes.

Methods: We performed cultures on selective and nonselective media from toothbrushes used by Dentistry students from State University of West Paraná (Unioeste/PR) to identify and quantify the number of total and specific microorganisms. For the chlorhexidine test, a crossover and double-blind study was conducted, with a random selection of volunteers. Each experimental phase consisted of fourteen days of brushing and an interval of seven days between treatments. For the test, thirty volunteers, divided into three groups of 10, using new toothbrushes, sprayed with either water or $0.12 \%$ chlorhexidine gluconate at different intervals (once or three times daily) after brushing. For statistical analysis, we used main effects ANOVA, and a $P$-value $<0.05$ was considered significant.

Results: There was microbial growth on $91 \%$ of the used toothbrushes, with $81.3 \%$ showing growth of Streptococcus. In 56.3\% of the brushes, Staphylococcus and Enterobacteriaceae developed. The use of the chlorhexidine spray only three times per day was significantly more effective than water.

Conclusion: Even in a group that knows the ideal conditions for the storage of toothbrushes, much microbial contamination still exists on the toothbrushes. A lower bacterial load can be obtained from the simple and inexpensive act of spraying chlorhexidine on the toothbrush after every brushing of the day.
\end{abstract}

Key words: Contamination; antisepsis; chlorhexidine

\section{Resumo}

Objetivo: Este trabalho verificou o índice de contaminação microbiológica de escovas dentais em uso por universitários e estabeleceu um protocolo para o borrifamento de clorexidina $0,12 \%$ para diminuir a presença bacteriana nas cerdas das escovas.

Métodos: Foram realizadas culturas em meios seletivos e não seletivos de escovas dentais em uso por acadêmicos do curso de Odontologia da Unioeste/PR para identificar e quantificar microrganismos totais e específicos. Para o teste com a clorexidina, foi realizado um estudo cruzado, duplo-cego com seleção aleatória dos voluntários em que cada fase experimental consistia de quatorze dias de escovação e sete dias de intervalo entre os tratamentos. Para o teste, trinta voluntários, divididos em três grupos de 10, utilizando escovas dentais novas, realizavam o borrifamento de água ou gluconato de clorexidina $0,12 \%$ com periodicidades diferentes (uma vez ou três vezes ao dia) seguidos à escovação. Para análise estatística foi utilizado uma ANOVA de efeitos principais e $P<0,05$ foi considerado significativo.

Resultados: Houve crescimento microbiano em $91 \%$ das escovas em uso, com $81,3 \%$ de crescimento de Streptococcus. Em 56,3\% das escovas houve desenvolvimento de Staphylococcus e de enterobactérias. Quanto à eficácia da clorexidina somente utilizando três borrifamentos diários obteve diferença significativa em relação ao grupo que utilizou água.

Conclusão: Mesmo em um grupo que tem conhecimento sobre as condições ideais para o armazenamento de escovas dentais, uma alta contaminação microbiana ainda existe. Uma menor carga bacteriana pode ser obtida a partir do uso de spray de clorexidina na escova após cada escovação diária.

Palavras-chave: Contaminação; antissepsia; clorexidina

\author{
Lais Kuhn Rodrigues a \\ Cintia Werner Motter a \\ Daniele Aiache Pegoraro a \\ Ana Paula Vicente Menoli b \\ Rafael Andrade Menolli a
}

- State University of West of Paraná (UNIOESTE), Cascavel, PR, Brazil

b School of Dentistry, University of Paraná (UNIPAR), Cascavel, PR, Brazil

\section{Correspondence:}

Rafael Andrade Menolli

State University of West of Paraná/UNIOESTE

School of Pharmacy

Universitária Street 2069

Cascavel, PR - Brazil

85819-110

E-mail: ramenolli@hotmail.com

Received: March 11, 2011

Accepted: August 29, 2011

Conflict of Interests: The authors state that there are no financial and personal conflicts of interest that could have inappropriately influenced their work.

Copyright: (c) 2012 Rodrigues et al.: licensee EDIPUCRS. This is an Open Access article distributed under the terms of the Creative Commons AttributionNoncommercial-No Derivative Works 3.0 Unported License. 


\section{Introduction}

Microbiological contamination of the oral cavity has long been a widely discussed topic and the subject of scientific publications; however, the same attention has not been given to the contamination of toothbrushes. Recently, the toothbrush has been characterized as a means of microbial transport, retention and growth $(1,2)$, and highly contaminated brushes may cause a possible constant "reinfection," which is a risk factor for periodontal disease (3).

Several articles have depicted the bacterial and fungal contamination of brushes, with higher or lower contamination being associated with numerous interferences placed between the brush and the handle $(4,5)$.

A number of procedures have been described to reduce the microbiological load of toothbrushes, such as continuous brush exchange (6), submerging the brush into microbicide solutions (7), spraying antiseptic solutions (8) or using ozone or UV (9), all of which have been successful in decontaminating the brushes but are not always inexpensive or easy to perform.

This work discusses the contamination of toothbrushes used by dental students and describes a decontamination method involving the spraying of $0.12 \%$ chlorhexidine. This method has been shown to be effective, but here, we study the effect of spraying frequency on the effectiveness of the method.

\section{Methods}

This research was approved by the Ethics Committee for Research-Unioeste/PR under the number 106/2006.

For the first experiment, all of the 80 students from the first and second academic year of the Unioeste/PR School of Dentistry were invited to participate, of which 32 agreed to participate by providing their toothbrushes. This experiment consisted of verifying the level of contamination present on the toothbrushes in use by the students. After the students signed an informed consent form, their toothbrushes were collected and taken to the Laboratory of Microbiology at Unioeste/PR and immersed in $1 \mathrm{~mL}$ sterile Tryptic Soy Broth (TSB) and vortexed for two minutes. The TSB was serially diluted and applied to plates with selective and specific media for the identification of certain groups of microorganisms: Blood Agar (BA) for facultative aerobes, Salivarius Mitis Agar (SMA) for total streptococci, Modified Bacitracin
Sucrose Agar (BSA) for mutans streptococci, McConkey Agar (MCA) for enterobacteria, Mannitol Salt Agar (MA) for staphylococci and Sabouraud agar (SBA) for yeasts. The BA, MCA, MA and SBA media were incubated under aerobic conditions, while the BSA and SMA media were placed in microaerophilic conditions. All of the media were incubated at $35-37{ }^{\circ} \mathrm{C}$ for 24 hours. Microbial growth was quantified using a digital colony counter. New toothbrushes were subjected to the same procedure as the used toothbrushes to be used as a negative control for microbial growth. The results were presented as frequency $(\%)$.

For the second experiment, thirty individuals, chosen randomly from a table of random numbers of the dental students at Unioeste/PR, signed the consent form and then underwent a double blind test to verify the decontaminant effectiveness on a toothbrush. The groups were divided using a randomized cross-over design, the arrangement of which is shown in Table 1.

Three solutions, numbered as 1,2 and 3, were delivered to groups of 10 students, and all individuals used the three solutions for one week. New toothbrushes and a tube of toothpaste (the toothpaste contained no antimicrobial solution) were always distributed one week before each scheme. The individuals brushed their teeth three times a day with the provided brushes without the antimicrobial solution for one week and with the antimicrobial solution for one week. Solution 2 was only water, and solutions 1 and 3 contained $0.12 \%$ chlorhexidine gluconate, obtained from a compounding pharmacy. The groups using solutions 1 and 2 applied the solution to the brush once a day after the first brushing of the day, and the group using solution 3 applied the solution after each brushing. The three groups were instructed to standardize the brushing and the amount of toothpaste on the brush. At the end of each two-week period, the toothbrushes were collected and given a number so that the handling could be performed blindly.

A new treatment cycle was started one week later ("washout" time). Each toothbrush was taken to the Laboratory of Microbiology at Unioeste/Cascavel, where it was immersed in $1 \mathrm{~mL}$ TSB and vortexed for two minutes. Next, serial TSB dilutions were applied to plates for the identification of microorganisms. The plates contained BA to quantify total microorganisms and MSA for total streptococci. The BA medium was incubated under aerobic conditions, and the MSA medium was incubated under microaerophilic conditions; both media were incubated at $35-37^{\circ} \mathrm{C}$ for
Table 1. Disposition of the randomized cross-over design applied among individuals under the decontamination protocol with $0.12 \%$ chlorhexidine

\begin{tabular}{cccc}
\hline \multirow{2}{*}{ Group } & \multicolumn{3}{c}{ Steps } \\
\cline { 2 - 4 } & $1^{\text {st }}$ step & $2^{\text {nd }}$ step & $3^{\text {rd }}$ step \\
\hline 10 individuals & Protocol 1 & Protocol 3 & Protocol 2 \\
10 individuals & Protocol 3 & Protocol 2 & Protocol 1 \\
10 individuals & Protocol 2 & Protocol 1 & Protocol 3 \\
\hline
\end{tabular}

Protocol 1 indicates brushing for one week with a new toothbrush without any treatment and a one-week brushing with daily spraying of $0.12 \%$ chlorhexidine. Protocol 2 indicates brushing for one week with a new toothbrush without any treatment and a one-week brushing with daily spraying with water. Protocol 3 indicates brushing for one week with a new toothbrush without any treatment and a one-week brushing with spraying after each brushing with $0.12 \%$ chlorhexidine. Between each protocol, a one-week interval ("wash-out" time) was used. 
24 hours. The growth was quantified using a digital colony counter. After the number of colonies growing on both media types was counted, a single count was collected, according to the spraying scheme, to evaluate the decontamination effectiveness. New brushes were subjected to the same procedure as those collected from the volunteers to be used as a negative control for microbial growth.

The statistical analysis of the second experiment was performed by ANOVA-main effects test, considering as variables the voluntary sequence, period, volunteer (random factor grouped in sequence), precedent ("carry over" effect) and treatments. The original data did not meet all of the requirements for evaluation by parametric tests; however, the log-transformation of the original data was used to fit these data. Tukey's test was used as a post hoc test. A $P$-value of $<0.05$ was considered to be significant for all evaluations. The results are shown in the form of the geometric means of the colony-forming units per milliliter with \pm a $95 \%$ confidence interval for each group analyzed.

\section{Results}

In the first experiment, $91 \%$ of the toothbrushes had some type of microbial growth on them. The amount of microorganisms varied widely, with some samples showing growth of more than $100,000 \mathrm{CFU} / \mathrm{mL}$ and other samples with only $100 \mathrm{CFU} / \mathrm{mL}$ (the detection threshold of the method used). Some level of growth of all of the tested microorganisms was demonstrated, as shown in Table 2. Streptococci was present in the most samples, with $81.3 \%$ of the toothbrushes $(n=26)$ presenting some growth of this organism. Specifically, mutans streptococci was detected on $46.9 \%$ of the brushes $(n=15)$. Staphylococci and enterobacteria were identified in $56.3 \%(n=18)$ of the samples. Yeast were found in only $9.4 \%(\mathrm{n}=3)$ of the brushes.

Table 2. Growth frequency (\%) of microorganisms on toothbrushes used by students from Unioeste/PR

\begin{tabular}{ccc}
\hline Microorganism group & Frequency (\%) & $\mathrm{n}$ \\
\hline Streptococci & 81.3 & 26 \\
Streptococcus mutans & 46.9 & 15 \\
Staphylococci & 56.3 & 18 \\
Enterobacteria & 56.3 & 18 \\
Yeast & 9.4 & 3 \\
\hline
\end{tabular}

Each group of microorganisms was also quantified, with concentrations divided into three different ranges [between 100-3000 CFU/mL (range 1), between 3100-10,000 CFU/mL (range 2) and above $10,000 \mathrm{CFU} / \mathrm{mL}$ (range 3)]. The quantification of all positive samples is listed in Table 3. The bacteria of the streptococci group (Streptococcus mutans) and the staphylococci group grew on the brushes most often within the first range (the range with lower growth). However, the growth of enterobacteria on most of the brushes developed within range 2 (the range with intermediate growth). On the few brushes that had yeast growth, the yeast were within the first range. No brush from the negative control group showed growth.

The results of experiment 2 are shown in Figure 1 and demonstrate an efficient decontamination with $0.12 \%$ chlorhexidine gluconate. Statistical analysis using the ANOVA-main effects test showed no "carry-over" effect (or sequence effect) that is common in crossed random tests, showing that the time used to "wash-out" was enough to prevent distortion of the results. The treatments with water

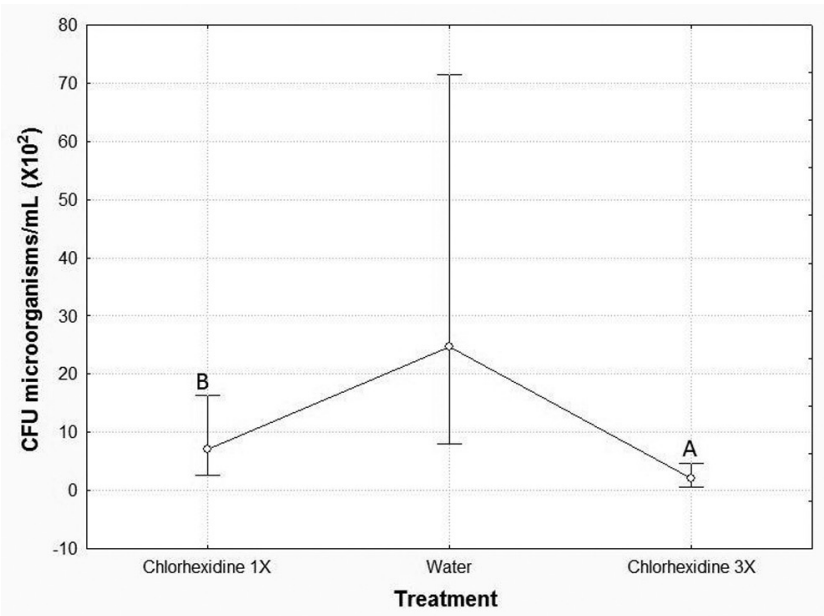

Fig. 1. Growth of total microorganisms in $\mathrm{CFU} / \mathrm{mL}\left(\mathrm{X} 10^{2}\right)$ in toothbrushes submitted to the use of $0.12 \%$ chlorhexidine gluconate three times a day, once a day and without the use of antiseptic (water). Values represent the geometric mean $\pm 95 \%$ confidence interval of values for microorganisms' growth. The letter " $A$ " represents the presence of statistical significance $(P<0.05)$ between treatment with chlorhexidine 3 times/day and water treatment, and the letter " $\mathrm{B}$ " indicates the absence of statistical significance $(P>0.05)$ between treatment with chlorhexidine once a day and water treatment.

Table 3. Frequency of development within the growth ranges of microorganisms isolated from toothbrushes used by Dentistry students at Unioeste/PR

\begin{tabular}{ccccc}
\hline Microorganism Group & $\begin{array}{c}\text { Range 1 } \\
(\% / \mathrm{n})\end{array}$ & $\begin{array}{c}\text { Range 2 } \\
(\% / \mathrm{n})\end{array}$ & $\begin{array}{c}\text { Range 3 } \\
(\% / \mathrm{n})\end{array}$ & $\begin{array}{c}\text { Total } \\
(\% / \mathrm{n})\end{array}$ \\
\hline Streptococci & $58 / 15$ & $31 / 8$ & $12 / 3$ & $100 / 26$ \\
Streptococcus mutans & $66 / 10$ & $33 / 5$ & $0 / 0$ & $100 / 15$ \\
Staphylococci & $50 / 9$ & $33 / 6$ & $17 / 3$ & $100 / 18$ \\
Enterobacteria & $29 / 4$ & $57 / 8$ & $14 / 2$ & $100 / 18$ \\
Yeast & $100 / 3$ & $0 / 0$ & $0 / 0$ & $100 / 3$ \\
\hline
\end{tabular}

Range 1 corresponds to growth in the range between 100 and $3000 \mathrm{CFU} / \mathrm{mL}$; Range 2 corresponds to growth in the range between 3,100 and $10,000 \mathrm{CFU} / \mathrm{mL}$; Range 3 corresponds to growth over $10,000 \mathrm{CFU} / \mathrm{mL}$. 
and chlorhexidine 1 or 3 times a day were compared using the ANOVA test. Only the treatment with chlorhexidine three times a day showed a significantly lower microbial growth $(P<0.05)$ than the treatment with water. The number of daily brushings significantly influenced the decrease in the number of microorganisms on the brushes, and although the chart shows a sharp drop in the number of microorganisms after the treatment with chlorhexidine once a day compared to the treatment with water, this decrease did not reach statistical significance. No brush from the negative control group showed microbial growth.

\section{Discussion}

It has been shown in the literature that toothbrushes are excellent locations for the growth of microorganisms $(10,11)$.

Microbial growth was detected on almost all of the brushes tested in this study ( $>90 \%)$, with development of streptococci observed on the vast majority of the brushes, which shows that toothbrushes are an excellent means of transport for bacteria. Nearly half of the brushes showed growth of mutans streptococci, members of the oral microbiota that are currently considered to be major cariogenic agents $(1,12)$. This finding highlights the ability of mutans streptococci to form biofilms and binding to the material of the toothbrushes (1).

Different population groups, such as children, adults or the elderly, may differ in their microbial load $(1,13)$, particularly in the effectiveness of their brushing. This study addressed a population with knowledge about the correct method of brushing, and the results indicate levels of contamination similar to those obtained by other studies $(6,5)$. Staphylococci were found in large numbers, on over $50 \%$ of the brushes. Although it belongs to the oral microbiota, Staphylococcus aureus deserves greater attention because it is capable of producing many oral infectious diseases.

The contamination by enterobacteria also draws attention, as it was found on more than $50 \%$ of the brushes, as a result of incorrect storage of brushes, most likely out of a closet and over the bathroom sink, where it is a target of aerosols from the toilet (14).

The growth of yeast varies greatly depending on the methodology and population used in the survey, with the population surveyed in this study being detected in low numbers compared to other studies $(5,11)$. The quantification of these organisms showed heterogeneity in growth for all types of microorganisms, ranging from a few CFU per milliliters to a virtually limitless growth depending on the methodology used. Such differences in growth may be a result of the different behaviors of the individuals in this research, including variations in the use of, for example, mouthwash containing antimicrobial solutions (15), the type of toothpaste (with or without antibiotics) (16) and the time of use of these items (17).

This study describes a protocol that is capable of standardizing the use of chlorhexidine, which is an antiseptic that is already widely used for the decontamination of the oral microbiota, for the daily decontamination of toothbrushes.

Several expedients have proven to be effective in controlling the microbial contamination of toothbrushes $(15,18)$, and other works $(8,19)$ have shown that chlorhexidine is effective, but a pattern regarding its periodicity has not yet been shown.

These results showed that the application of a single spraying of chlorhexidine per day greatly reduced, although with no statistical significance, the presence of bacteria, with an $80.21 \%$ decrease comparing the group treated once per day with the negative control, which suggests that chlorhexidine at low concentrations $(0.12 \%)$ can act as an expedient to avoid a possible source of reinfection.

A significant decrease was found in the spraying of $0.12 \%$ chlorhexidine three times a day after every brushing, with a $90.17 \%$ decrease compared to the negative control and a $63.36 \%$ decrease compared to the strategy of daily spraying with chlorhexidine.

This procedure could become an after-brushing habit on a day-to-day basis for the general population because the spraying, a simple and easily understandable act, was performed with a technique that can be assimilated by any person without the need for specific skills. This approach makes this procedure different from other antiseptic brush techniques that have been tested, which were effective strategies to prevent microbial growth but were hindered by their need to be performed on a daily basis $(6,9)$.

One advantage of chlorhexidine gluconate is its cost/ benefit, as it is an inexpensive antiseptic that can be purchased in specialized pharmacies or in the processed form (Periogard ${ }^{\circledR}$ - Colgate Palmolive), with both forms having similar efficacy (20).

Population groups at risk, such as those that are immunocompromised, may have serious infections that are caused by oral microorganisms (21), and these groups may benefit from the routine use of chlorhexidine on their brushes, thus preventing contamination caused by daily reexposure to microorganisms housed in toothbrushes.

\section{Conclusion}

The results of this study showed that the use of $0.12 \%$ chlorhexidine after three daily brushings is effective as an antiseptic technique for toothbrushes, establishing a stilllacking protocol for the after-brushing antisepsis procedure with chlorhexidine. It became clear that contamination of toothbrushes occurs often, even in individuals who should know the ideal conditions for the storage of toothbrushes. 
1. Wetzel WE, Schaumburg C, Ansari F, Kroeger T, Sziegoleit A. Microbial contamination of toothbrushes with different principles of filament anchoring. J Am Dent Assoc 2005; 136:758-65.

2. Nelson Filho P, Macari S, Faria G, Assed S, Ito IY. Microbial contamination of toothbrushes and their decontamination. Pediatric Dent 2000;22:381-4.

3. Goldschmidt MC, Warren DP, Keene HJ, Tate WH, Gowda C. Effects of an antimicrobial additive to toothbrushes on residual periodontal pathogens. J Clin Dent 2004;15:66-70.

4. Bhat SS, Hedge KS, George RM. Microbial contamination of toothbrushes and their decontamination. J Ind Soc Pedi Prev Dent 2003;21:108-12.

5. Mehta A, Sequeira PS, Bhat G. Bacterial contamination and decontamination of toothbrushes after use. N Y State Dent J 2007;73:20-2.

6. Pai V. Effect of a single use toothbrush on plaque microflora. Indian J Dent Res 2009; 20:404-6.

7. Komyiama EY, Back-Brito GN, Balducci I, Koga-lto CY. Evaluation of alternative methods for the disinfection methods of toothbrushes. Braz Oral Res 2010;24:28-33.

8. Sato S, Pedrazzi V, Lara EHG, Panzeri H, Albuquerque Jr RF, Ito IY. Antimicrobial spray for toothbrush disinfection: an in vivo evaluation. Quintessence Int 2005;36:812-16.

9. Bezirtzoglou E, Cretoiu SM, Moldoveanu M, Alexopoulos A, Lazar V, Nakou M. A quantitative approach to the effectiveness of ozone against microbiota organisms colonizing toothbrushes. J Dent 2008;36:600-5.

10. Dayoub MB, Rusilko D, Gross A. Microbial contamination of toothbrushes. J Dent Res 1977;56:706

11. Taii S, Rogers A. The microbial contamination of toothbrushes. A pilot study. Aust Dent J 1998;43:128-30.

12. Napimoga MH, Höfling IF, Klein MI, Kamiya RU, Gonçalves RB. Transmission, diversity and virulence factors of Streptococcus mutans genotypes. J Oral Sci 2005;47:59-64.

13. Nelson Filho P, Faria G, da Silva RAB, Rossi MA, Ito IY. Evaluation of the contamination and disinfection methods of toothbrushes used by 24 to 48 month old children. J Dent Child 2006;73:152-8.

14. Long SR, Dos Santos AS, Nascimento CMO. Avaliação da contaminação de escovas dentais por enterobactérias. Rev Odontol Univ Santo Amaro 2000;5:21-5.

15. Balappanavara AY, Nagesh L, Ankola AV, Tangade PS, Kakodkar P, Varun S. Antimicrobial efficacy of various disinfecting solutions in reducing the contamination of the toothbrush - a comparative study. Oral Health Prev Dent 2009;7:137-45.

16. Lima MVV, Watanabe E, Faria G, Nascimento AP, Verri MP, Ito IY. Biofilme: avaliação do nível de contaminação de escovas dentais monobloc ${ }^{\circledR}$ em função do dentifrício. Rev Odonto Ciênc 2007;22:269-74.

17. Sogi SH, Reddy SD, Kiran SN. Contamination of toothbrush at different time intervals and effectiveness of various disinfecting solutions in reducing the contamination. J. Indian Soc Pedod Prev Dent 2002;20:81-5.

18. Ankola AV, Hebbal M, Eshwar S. How clean is the toothbrush that cleans your tooth? Int J Dent Hygiene 2009; 7: 237-40.

19. Ayşegül Ö, Elgin IE, Gulcin A, Nedim S. The effıcacy of chlorhexidine spray vs. mouthwash in the microbial contamination of child toothbrushes. J Dent Child 2007;74:177-81.

20. Segundo AS, Bosco AF, Semenoff TADV, Rocatto GEGD, Cirilo DM, Buzelle SL et al. Efetividade do gluconato de clorexidina a $0,12 \%$ e do digluconato de clorexidina a $2 \%$ adquiridos em diferentes dentais e farmácias na cidade de Cuiabá, sobre Candida albicans. Rev Period 2007;17:41-5.

21. Kennedy HF, Morrison D, Tomlinson D, Gibson BES, Bagg J, Gemmell CG. Gingivitis and toothbrushes: potential roles in viridans streptococcal bacteraemia. J Infect 2003;46:67-70. 